\title{
Information Filtering with Extracted Index Words Using ICA
}

\author{
Takeru Yokoi Member (Tokyo Metropolitan College of Industrial Technology, takeru@s.metro-cit.ac.jp) \\ Hidekazu Yanagimoto Member (Osaka Prefecture University, hidekazu@cs.osakafu-u.ac.jp) \\ Sigeru Omatu Member (Osaka Prefecture University, omatu@cs.osakafu-u.ac.jp)
}

Keywords: information filtering, index words selection, independent component analysis, user profile

We propose an information filtering system with extracted index words using Independent Component Analysis (ICA). Elements of a document vector are established as the weights of the index words and their dimensions become larger as the number of documents increase. Therefore, from the viewpoint of efficiency in processing time and memory space, the dimension should be decreased. The proposed method can decrease the dimension by selecting index words based on the topics included in the corpus. We have applied ICA to the documents to obtain the topics. Filtering by the relevance feedback with the document vectors reconstructed by the selected index words is then carried out to confirm the effectiveness of our proposed method.

ICA is a method in finding statistically independent signal sources from only the observed signals. ICA assumes the observed signals are described by linear combinations of statistically independent signals. $D$ denotes the observed signals and, $S$ denotes statistically independent signals. An ICA model is defined as:

$$
D=A S
$$

where $A$ is the mixing matrix. When ICA is applied to documents, the observed matrix $D$ corresponds to a documentword matrix and the independent signal $S$ corresponds to the topics. $D$ and $S$ are represented as follows:

$$
\begin{aligned}
D & =\left[\begin{array}{llll}
\mathbf{d}_{1} & \mathbf{d}_{2} & \cdots & \mathbf{d}_{n}
\end{array}\right]^{T} \\
S & =\left[\begin{array}{llll}
\mathbf{s}_{1} & \mathbf{s}_{2} & \cdots & \mathbf{s}_{m}
\end{array}\right]^{T}
\end{aligned}
$$

where $\mathbf{d}_{i}$ is the document vector and $\mathbf{s}_{j}$ is the topic. To estimate the independent components, Fast ICA algorithm was adopted. As an independent measure, negentoropy was applied. In addition, words which carry maximum or minimum weight in each topic are extracted as the key words. Here, each key word is denoted by $g$ and a set of those key words by $G$.

Next, to select the co-occurring words based on the key words, the $\chi^{2}$-measure value is used. In this paper, the $\chi^{2}$-measure evaluates the difference between the actual frequency and expected frequency of the co-occurrence of a word and the key words. Words whose $\chi^{2}$-measure value are high as co-occurring words are selected. That is, since the high $\chi^{2}$ value identifies the co-occurrence of specialized key words, those words are considered to be important. Here, $t$ denotes the words excluding the key words in a corpus. The expected probability $p_{g}$ denotes an unconditional probability of a key word $g$ while $n_{t}$ denotes the frequency of the co-occurrence of the word $t$ and the set of the key words $G$. The frequency of the co-occurrence of the word $t$ and the key word $g$ is denoted as freq $(t, g) \cdot \chi^{2}(t)$ which identifies the $\chi^{2}$-measure value of the word $t$ is defined as follows:

$$
\chi^{2}(t)=\sum_{g \in G} \frac{\left(\text { freq }(t, g)-n_{t} p_{g}\right)^{2}}{n_{t} p_{g}} \ldots
$$

The document vector is reconstructed with the key words and the co-occurring words whose $\chi^{2}$ values are high as the index words, and construct an user profile.

When we construct the user profile $\mathbf{u}$, Relevance Feedback is adopted, as follows:

$$
\mathbf{u}=\sum_{\mathbf{d}_{i} \in D_{I}} \mathbf{d}_{i}-N_{I} / N_{U} \sum_{\mathbf{d}_{j} \in D_{U}} \mathbf{d}_{j} \ldots \ldots \ldots \ldots \ldots
$$

where $D_{I}$ denotes the set of interesting documents, $D_{U}$ denotes the set of uninteresting documents, $N_{I}$ and $N_{U}$ denote the numbers of interesting documents and uninteresting documents, respectively.

As experimental data, 9 tasks in NTCIR2 are used. In experiments, the numbers of key words and index words are then changed. The number of index words is established as $10 \%, 30 \%$ and $50 \%$ of all words included in a corpus. Table 1 shows the best 11-point average precision of the proposed method (PROP) in each task and the original (ORIG) for comparison.

As can be seen by these results, our proposed method is useful since the precisions are the same or better even when the dimension of the document vector is decreased.

Table 1. 11-points average precision

\begin{tabular}{|l|l|l|l|l|l|l|l|l|l|}
\hline Task & 109 & 110 & 111 & 114 & 115 & 119 & 121 & 147 & 148 \\
\hline \hline ORIG & 0.60 & 0.25 & 0.72 & 0.38 & 0.61 & 0.63 & 0.72 & 0.82 & 0.05 \\
\hline PROP & 0.61 & 0.25 & 0.71 & 0.41 & 0.60 & 0.56 & 0.71 & 0.82 & 0.13 \\
\hline
\end{tabular}




\title{
ICAによる索引語抽出を用いた情報フィルタリング
}

\author{
正員 横井 健* 正 員 柳本 豪一** \\ 正員大松繁**
}

\author{
Information Filtering with Extracted Index Words Using ICA
}

Takeru Yokoi*, Member, Hidekazu Yanagimoto**, Member, Sigeru Omatu**, Member

We propose an information filtering system with extracted index words using by Independent Component Analysis(ICA). Elements of a document vector are established as the weights of index words and their dimensions become larger as the number of documents is increased. Therefore, from the view point of processing time and memory space, the dimension must be decreased. The proposed method decreases the dimension by selecting the index words based on the topics included in the corpus. We have applied ICA to the documents to obtain the topics. Then filtering by the relevance feedback with the document vectors reconstructed by the selected index words, was carried out to confirm the effectiveness of the proposed method.

キーワード : 情報フィルタリング, 索引語選別, 独立成分分析, ユーザープロファイル

Keywords: information filtering, index words selection, independent component analysis, user profile

\section{1. はじめに}

近年，急速に情報化が進み，数多くの情報がインターネッ トに代表されるネットワークを通じて公開されるようになっ た。その流れの中で，ユーザが求める情報を探すために， データベース検索を利用した検索システムが数多く開発さ れてきた。しかし，従来のシステムでは，ユーザにとって必 要な情報を取得することが困難になってきた。例えば，ユー ザーにとって必要な情報が, 膨大な情報の中に埋もれてし まう情報洪水(1) という現象が発生してきたことがあげられ る。この情報洪水の現象を解決するために，ユーザの興味 に応じてドキュメントの表示順序をソーティングするラン キング手法や, 必要な情報のみを選択する情報フィルタリ ングが提案されている。

ドキュメントを対象とした情報フィルタリングにおいて， ベクトル空間法 ${ }^{(2)}$ によるドキュメントのベクトル表現が しばしば用いられる。ドキュメントベクトルは，ドキュメ

\footnotetext{
*東京都立産業技術高等専門学校 ものづくり工学科 電子情報工学 コース

テ 140-0011 品川区東大井 1-10-40

Tokyo Metropolitan College of Industrial Technology Monozukuri Department Electronics and Information Engineering Course 1-10-40, Higashi-Oi, Shinagawa-ku, 140-0011

** 大阪府立大学 工学部 知能情報工学科

干 599-8531 堺市中区学園町 1 番 1 号

Osaka Prefecture University Engineer Department Computer Science and Intelligent Systems

1-1, Gakuen-cho, Naka-ku, Sakai, 599-8531
}

ント中に含まれる語（索引語）に対する重みを要素とする ベクトルとしてドキュメントを表現するものである。一般 に，扱うドキュメント数が多くなるにつれて索引語は増加 していくため, ドキュメントベクトルの次元数も大きくな り，処理に必要なメモリや時間も増加する。そこで，索引 語を選別することにより，ドキュメントベクトルを低次元 化することを考える。

文献 $(3),(4)$ では，単語間の共起関係に着目して，ドキュ メント中から重要な語を抽出する手法が提案されている。 これらの手法では，ドキュメントないしドキュメント集合 中における高頻度語とその単語を基準として頻繁に共起し ている単語を重要語としている。本論文では,このような 重要語をドキュメントベクトルの索引語として用いること を考える。索引語選別の過程において, 基準となる語によっ て索引語が異なってくるので, その基準となる語の選別は 重要である。そこで, 出現頻度という基準ではなく, ドキュ メント集合に含まれるトピックという概念に基づいて，そ れらの基準となる語を選別することを提案する。基準とな る語をトピックという概念から捉えることにより，ドキュ メント集合中のトピックを漏らすことなく索引語として選 別できると考えられる。

ドキュメントのトピックを求める手法として, 独立成分 分析 (ICA; Independent Component Analysis) (5) があ る。ドキュメントベクトルを入力信号に見立てて ICA を適 用すると，その得られる独立成分がドキュメント中のトピッ クであると報告されている (6) (7)。著者らは文献 (8)におい 
て，ICA をドキュメントに適用して得られるトピックの一 部が，コーパス中の特定のトピックを細分化したものであ ることを確認している。したがって，そのような細分化さ れた小さなトピックを捉えることで，抽出すべきドキュメ ントの特徴をより的確に把握でき，フィルタリングの精度 改善につながると考えられる。

本論文では，ICAによりドキュメント中からトピックを 求め, そのトピック中の重要語を基準として文献 (3) と同 様に， $\chi^{2}$ 值により共起語を選別する。得られた基準語と共 起語を合わせて索引語とし，それらを用いてドキュメント ベクトルを再構築し，関連フィードバック (9) によるフィル タリングを行い, 提案手法の有効性を確認する。このとき, 従来のベクトル低次元化手法の一つである $\mathrm{LSA}^{(10)}$ との比 較を行う。

\section{2. 関連研究}

ドキュメントベクトルの低次元化の方法としては，従来， 潜在的意味解析 (LSA; Latent Semantic Analysis) ${ }^{(10)}$ が しばしば用いられている。LSA は，特異值分解により特異 ベクトルを求め, 小さな特異值に対応する特異べクトルを 削除することで，ドキュメントベクトルを低次元化する。 この特異ベクトルを潜在的意味と呼ぶ。

本論文では，潜在的意味空間上の軸を求めるのではなく， 索引語の選別によりベクトルの低次元化を実現する。提案 する索引語選別の方法は, 文献 (3) にヒントを得たもので ある。文献 (3) では，単一ドキュメントから，重要語を選 別する手法を報告している。具体的には，ドキュメント中 の高頻度語を基準にし，ある語の実際の共起頻度とその予 測值が大きく異なるものをドキュメント中における重要語 としている。また，その予測值とのずれを判定するために $\chi^{2}$ 值を用いている。一方, 文献 (4) では, Web 上のページ から重要語を抽出する手法を提案している。ここでは，高 頻度語を基準とし，Key Graphを用いて関連性の高い単語 を抽出している。

文献 (3) では，単一ドキュメント中から重要語を選別す るため, 高頻度語=その文書の特徴語と考えることができ た。しかし，それをドキュメント集合に適用する場合，単 一のドキュメントと異なり，コーパス中には大小さまざま なトピックを持ったドキュメントが含まれているので，そ れらの中で小さなトピックを表す基準語が高頻度語では抽 出できないと考えられる。そこで，本論文では，上述の基 準となる語の選別に ICA によって得られるトピックを利 用する。我々は，文献 $(8)$ において，ICA によってコーパ ス内に含まれる細分化されたトピックを取得できることを 確認している。トピックを細分化して解析することにより， ドキュメントの特徴をより的確に捉えることができ，フィ ルタリング精度の改善に寄与すると考えられる。

\section{3. 提案手法}

本論文では，ICA によって得られるトピックを用いて索
引語を決定する。そこで，得られた索引語を用いて，ドキュ メントベクトルを作成する。最後に, 関連フィードバック 法により作成したユーザプロファイルを用いて推薦を行い, 提案した索引語選別の有効性を検討する。本章では，ドキュ メントベクトルとユーザープロファイル，ICA を利用した トピックの基準語を抽出する方法，および，ICA によって得 られた基準語から索引語を選別する方法について説明する。

$\langle\mathbf{3} \cdot \mathbf{1}\rangle$ ユーザープロファイル ベクトル空間法 ${ }^{(2)} に$ おいてドキュメントは, 索引語に対する重みを要素とする 列ベクトルで表現される。以下では，これをドキュメント ベクトルという。ある $i$ 番目のドキュメントに対して，索 引語数を $V$ とし， $j$ 番目の索引語に対する重みを $w_{i j}$ とす ると，ドキュメントベクトル $\mathbf{d}_{i}$ は，

$$
\mathbf{d}_{i}=\left[\begin{array}{llll}
w_{i 1} & w_{i 2} & \cdots & w_{i V}
\end{array}\right]^{T} \ldots \ldots \ldots \ldots \ldots
$$

で表される。[· $]^{T}$ は転置を示し, $w_{i j}$ は, tf-idf 法 ${ }^{(14)}$ によ り求める。tf-idf 法による $w_{i j}$ の求め方を $(2)$ 式に示す。

$$
w_{i j}=t f_{i j} \log \left(\frac{n}{d f_{j}}\right)
$$

ここで, $t f_{i j}$ は $i$ 番目のドキュメント中の $j$ 番目の索引語 の出現頻度, $d f_{j}$ は, $j$ 番目の索引語を含むドキュメント 数を表している。また， $n$ は全ドキュメント数を表す。

ユーザーの興味を表現したユーザープロファイル $\mathbf{u}$ は， (3) 式に示すように，索引語に対する重みを要素とした列 ベクトルとする。

$$
\mathbf{u}=\left[\begin{array}{llll}
u_{1} & u_{2} & \cdots & u_{V}
\end{array}\right]^{T} \ldots \ldots \ldots \ldots \ldots \ldots
$$

ユーザープロファイルの要素としては，興味のある索引語 には大きな重みを付け，興味のない索引語には小さな重み を付けるようにする。それゆえ，ドキュメントを用いて作 成される場合，興味のあるドキュメントに含まれる索引語 が大きな重みを持つことになる。ここでは，情報検索では よく知られた, 関連フィードバック法を用いて以下のユー ザープロファイルを構成する。

$$
\mathbf{u}=\alpha \sum_{\mathbf{d}_{k} \in D_{I}} \mathbf{d}_{k}-\beta \sum_{\mathbf{d}_{l} \in D_{U}} \mathbf{d}_{l} \ldots \ldots \ldots \ldots \ldots
$$

ここで， $\mathbf{u}$ はユーザープロファイル $, \mathbf{d}_{k}, \mathbf{d}_{l}$ はドキュメン トベクトル， $\alpha, \beta$ はドキュメントごとに設定した重み係 数である。 $D_{I}$ は興味のあるドキュメントの集合, $D_{U}$ は 興味のないドキュメントの集合である。

〈3·2〉 ドキュメントに対する ICA と基準語抽出 ICA は複数の観測された混合信号を統計的に独立な信号に分離 する手法である。ICAをドキュメントに適用する場合, ICA の観測信号系列をドキュメントベクトルとする。そのとき， 独立変数はそのドキュメント中に含まれるトピックを表す と仮定する。ここでトピックとはそのドキュメントに関連 のある分野を表すものであり，ドキュメントベクトルと同 じく，索引語に対する重みで表されるとする。各トピック 
に含まれる単語はトピック毎に偏りがあるので, この仮定 は妥当であると考えられる。

いま， $n$ 個のドキュメントベクトルを $\mathbf{d}_{1}, \mathbf{d}_{2}, \cdots, \mathbf{d}_{n}$ と し，このドキュメントベクトルが未知の $m$ 個のトピックの ベクトル $\mathbf{s}_{1}, \mathbf{s}_{2}, \cdots, \mathbf{s}_{m}$ の線形結合で与えられると仮定す る。なお，トピックベクトル $\mathbf{s}_{i}$ は互いに統計的に独立であ り，その平均值はゼロとする。ドキュメントベクトル数よ りトピック数の次元が多いと, 解が一意に定まらないので, $n \geq m$ とする。いま，ドキュメントベクトルとトピックベ クトルを並べた行列は，(5) 式のようになる。

$$
\begin{aligned}
D & =\left[\begin{array}{llll}
\mathbf{d}_{1} & \mathbf{d}_{2} & \cdots & \mathbf{d}_{n}
\end{array}\right]^{T} \\
& =\left[\begin{array}{llll}
\mathbf{t}_{d 1} & \mathbf{t}_{d 2} & \cdots & \mathbf{t}_{d V}
\end{array}\right] \\
S & =\left[\begin{array}{llll}
\mathbf{s}_{1} & \mathbf{s}_{2} & \cdots & \mathbf{s}_{m}
\end{array}\right]^{T} \\
& =\left[\begin{array}{llll}
\mathbf{t}_{s 1} & \mathbf{t}_{s 2} & \cdots & \mathbf{t}_{s V}
\end{array}\right]
\end{aligned}
$$

なお, 本研究では, $m$ を $D$ のランク数とする。ここで, $\mathbf{t}_{d j}$ は，次式のように定義する。

$$
\mathbf{t}_{d j}=\left[\begin{array}{llll}
w_{1 j} & w_{2 j} & \cdots & w_{n j}
\end{array}\right]^{T} \cdots
$$

$\mathbf{t}_{d j}$ は各ドキュメントを単語の重みによりベクトル化した ものである。一方， $\mathbf{t}_{s j}$ も単語の重みを用いて，(6) 式の $d$ を $s$ に置換したもので定義する。

ここで, $\mathbf{t}_{d j}$ の各単語の重みは, 各トピックに含まれる 単語の重み $\mathbf{t}_{s j}$ の混合であると考える。つまり, $\mathbf{t}_{d j}$ を(7) 式のモデルで表現する。

$$
\mathbf{t}_{d j}=A \mathbf{t}_{s j}
$$

$A$ は未知の $n \times m$ フルランク混合行列である。

(7) 式は，すべての $\mathbf{t}_{d j}$ で成立するので，行列を用いて (8) 式のように記述できる。

$$
D=A S
$$

ICA は, 混合行列 $A$ が未知の場合に, ドキュメントベク トル行列 $D$ だけを用いて, トピック行列 $S$ を推定する手 法である。ICA の実際の処理に扔いては， $S$ を推定するた めに, ドキュメントベクトル行列 $D$ のみから, 混合行列 $A$ の一般化逆行列 $W$ を推定する,

$$
W D=\left[\begin{array}{llll}
\mathbf{y}_{1} & \mathbf{y}_{2} & \cdots & \mathbf{y}_{m}
\end{array}\right]^{T}=Y
$$

ただし，復元信号 $Y$ はその列ベクトル $\mathbf{y}_{i}$ が互いに統計的 独立となるように求める。評価規範の性質から $Y$ の成分の 大きさと順序には任意性が残る ${ }^{(5)}$ 。

ICA における復元行列 $W$ を高速に推定する手法として, Fast ICA ${ }^{(5)}$ が提案されている。本論文ではこの Fast ICA を用いて，独立成分を求める。Fast ICA で利用される更 新式は，Negentoropyによる (10) 式を用いる。

$$
\begin{aligned}
& \mathbf{w}_{\text {new }}=E\left[\begin{array}{l}
\left.Y g\left(\mathbf{w}_{\text {old }}^{T} Y\right)\right]-E\left[g^{\prime}\left(\mathbf{w}_{\text {old }}^{T} Y\right)\right] \mathbf{w}_{\text {old }} \\
\ldots \ldots \ldots \ldots \ldots \ldots \ldots
\end{array}\right. \\
& g(\mathbf{v})=\left[\begin{array}{llll}
\tanh \left(v_{1}\right) & \tanh \left(v_{2}\right) & \ldots & \tanh \left(v_{V}\right)
\end{array}\right]^{T}
\end{aligned}
$$

$$
g^{\prime}(\mathbf{v}) \triangleq \frac{\partial g(\mathbf{v})}{\partial \mathbf{v}}=\left[\begin{array}{ccc}
\frac{\partial g\left(v_{1}\right)}{\partial v_{1}} & \ldots & \frac{\partial g\left(v_{1}\right)}{\partial v_{V}} \\
\vdots & \ddots & \vdots \\
\frac{\partial g\left(v_{V}\right)}{\partial v_{1}} & \ldots & \frac{\partial g\left(v_{V}\right)}{\partial v_{V}}
\end{array}\right]
$$

ここで, $E[\cdot]$ は期待值を表す。ICA によって求められた $Y$ の成分は，互いに統計的独立で $S$ と同等である。したがっ て，Yが入力ドキュメント中に含まれるトピックを表現し ている。

さらに，上述の手法によって得られた独立成分（トピッ ク）から, 本論文では, そのトピックをもっとも特徽づけ る単語を抽出する。ICAによって得られるトピックは, 単 語に対する重みで表現されているので, その重みのもっと も大きい単語が, そのトピックをもっとも象徵する単語で あると考えられる。それらの単語をここでは基準語 $g$ と呼 ぶ。具体的には, 各成分の最大もしくは最小の重みを持つ 単語を基準語とする。最大もしくは最小をとるのは, ICA によって得られる独立成分には符号の任意性が存在するた めである。また，そのようにして各成分から得られた基準 語の集合を $G$ で表記する。

$\langle\mathbf{3} \cdot \mathbf{3}\rangle \quad \chi^{2}$ 值を用いた索引語の選別 $\langle 3 \cdot 2$ 節で得た 基準語のうち, ある特定の基準語との久頻繁に共起する単 語は，その基準語同様，トピックを特徵づける単語である と考えられる。したがって, トピックから得られた基準語 とそれら共起する特徵的な単語を合わせて索引語として用 いれば，ドキュメント集合中に含まれるトピックに関連し た単語のみで索引語を構成でき，ノイズと考えられる一般 的な単語を除去し, 索引語の選別が行えると考えられる。

それらのトピックを特徵づける共起語を選別するために， 本論文では, 各単語が基準語 $g$ と共起する頻度と, その共 起頻度の予測值とのずれに着目する。このずれは $\chi^{2}$ 值を用 いて評価する。ここで, 基準語以外の単語を $t$ とする。も し, 単語 $t$ がある限られた基準語 $g$ と多く共起していれば, $\chi^{2}$ 值は大きくなる。逆に, 単語 $t$ がどの基準語ともまんべ んなく共起していたならば， $\chi^{2}$ 值は小さいものとなる。そ れゆえ， $\chi^{2}$ 值の高い単語を選べば，トピックを表す基準語 に関連深い特徵的な単語を抽出できる。

$p_{g}$ を基準語集合 $G$ 中の $g$ の出現確率とすると, 次のよ うに表せる。

$$
p_{g}=\frac{g \text { を含むドキュメント数 }}{G \text { を含む全ドキュメント数 }}
$$

また, $n_{t}$ を単語 $t$ と基準語集合 $G$ の共起頻度, freq $(t, g)$ を単語 $t$ と基準語 $g$ との共起頻度とすると, 単語 $t$ の $\chi^{2}$ 値 は次のようになる。

$$
\chi^{2}(t)=\sum_{g \in G} \frac{\left(\text { freq }(t, g)-n_{t} p_{g}\right)^{2}}{n_{t} p_{g}}
$$

なお, 本論文では, $t$ と $g$ が共起するとは, 同一ドキュメ ント中にそれら両方が含まれていると定義する。

\section{4. 実験と結果}

本章では, 提案手法によって得られる索引語を用いて作 
成したユーザープロファイルの有効性を確認するために行っ た評価実験について説明する。

$\langle\mathbf{4} \cdot \mathbf{1}\rangle$ 実験方法 まず，本手法の有効性を確認する ために，小規模なデータにおいて実験を行った。その実験 では，4 件の興味ありドキュメントを含む 100 件のドキュ メントを，それぞれ，興味ありドキュメントを 2 件ずつ含 む 80 件の学習データと 20 件の評価データに分割した。そ の後, さらなる有効性の検討のため, テストコレクション NTCIR2 ${ }^{(12)}$ から, 表 1 に示す 9 つのスクに含まれるデー 夕を用いてそれぞれ実験を行った。NTCIR2 のドキュメン トにはあらかじめタスクとの関連度合いとして， S から C までのランク付けがされている。本論文では，C 評価が付 いているドキュメントを興味のないドキュメントとし, 残 りのドキュメントを興味のあるドキュメントとした。

ドキュメントベクトルを作成するために，まず，茶鉒 ${ }^{(13)}$ を用いてすべてのドキュメントに対して形態素解析を行い, 名詞を抽出した。その後, 得られた単語に対して tf-idf 法 ${ }^{(14)}$ を用いて重み付けを行い，ドキュメントベクトルを作成した。

これらのドキュメントベクトルに対して，ICAを適用し， 各独立成分から一つずつ基準語を抽出した。このとき得ら れた基準語の数を全基準語数 $(A L L)$ とする。また，上記 の手順で得られた全基準語から，基準語数割合 $R_{b}$ に応じ て基準語を削減した場合の実験を行った。基準語数割合 $R_{b}$ は次式で定義する。

$$
R_{b}=\frac{\text { 使用基準語数 }}{\text { 全基準語数 }(A L L)} \times 100(\%) \cdots \cdots \cdots
$$

本論文では， $R_{b}=30 \%, R_{b}=10 \%$ の場合について実験 を行った。なお，基準語を削減する場合については，独立成 分の出現順序には任意性があるので，ドキュメント集合中 における出現頻度の多い単語を選んだ。表 2 に, NTCIR2 を用いた各実験におけるデータごとの基準語数を示す。

\section{表 1 実験デー夕}

Table 1. The experimental data.

\begin{tabular}{|l|l|l|l|}
\hline Task No. & Doc.\# & Interest Doc.\# & Index words \# \\
\hline \hline 109 & 453 & 21 & 6,537 \\
\hline 110 & 625 & 34 & 5,448 \\
\hline 111 & 540 & 40 & 8,257 \\
\hline 114 & 612 & 20 & 8,709 \\
\hline 115 & 930 & 94 & 12,055 \\
\hline 119 & 380 & 20 & 8,388 \\
\hline 121 & 500 & 63 & 6,258 \\
\hline 147 & 550 & 80 & 9,018 \\
\hline 148 & 480 & 14 & 6,990 \\
\hline
\end{tabular}

表 2 各実験における基準語数

Table 2. The number of the basic words in each experiment.

\begin{tabular}{|l|l|l|l|l|l|l|l|l|l|}
\hline Task No. & 109 & 110 & 111 & 114 & 115 & 119 & 121 & 147 & 148 \\
\hline \hline $10 \%$ & 45 & 60 & 55 & 62 & 95 & 38 & 50 & 55 & 46 \\
\hline $30 \%$ & 146 & 205 & 163 & 185 & 273 & 107 & 158 & 170 & 140 \\
\hline$A L L$ & 441 & 608 & 518 & 597 & 889 & 368 & 484 & 532 & 462 \\
\hline
\end{tabular}

そのようにして得られた基準語を用いて， $\chi^{2}$ 值により共 起語を選別し, 基準語と合わせて索引語とした。なお, 選 別する索引語数は選別索引語数割合 $R_{i}$ に基づいて決定し た。 $R_{i}$ は次式で定義する。

$$
R_{i}=\frac{\text { 選別後の索引語数 }}{\text { 選別前の索引語数 }} \times 100(\%)
$$

本論文では， $R_{i}=50 \%, R_{i}=30 \%, R_{i}=10 \%$ について 実験を行った。

最後に, 得られた索引語を用いてドキュメントベクトル を作成し直し，関連フィードバックによりユーザープロファ イル $\mathbf{u}$ を作成した。ユーザープロファイルの作成には，(4) 式を利用した。また，(4) 式中の係数 $\alpha$ と $\beta$ によって，作 成されるユーザプロファイルの推薦精度は変化すると考え られるが，ここでは，Roccioの式において用いられている 係数をもとに, 興味のあるドキュメントと興味のないドキュ メントの影響の比率が $1: 1$ になるように次のように $\alpha$ と $\beta$ を設定した。

$$
\begin{aligned}
& \alpha=+1 \\
& \beta=N_{I} / N_{U}
\end{aligned}
$$

$N_{I}$ は興味のあるドキュメントの総数, $N_{U}$ は興味のない ドキュメントの総数を表す。また，そのユーザープロファ イルを用いて (16) 式で求められる類似度 Sim に基づいて 推薦を行い, 11 点平均適合率によりそのユーザープロファ イルの評価を行った。

$$
S i m=\mathbf{u}^{T} \mathbf{d}_{i}
$$

11 点平均適合率は， 0 から 1 まで 0.1 刻みで再現率を変化 させたときの各再現率における適合率の平均值である。適 合率は (17) 式, 再現率は (18) 式で定義される。

$$
\begin{aligned}
& \text { 適合率 }=\frac{\text { 検索された文書中の該当文書数 }}{\text { 検索された文書数 }} \ldots \\
& \text { 再現率 }=\frac{\text { 検索された文書中の該当文書数 }}{\text { 全文書中の該当文書数 }} \ldots
\end{aligned}
$$

以下に実験の流れをまとめる。

（1）ベクトル空間法によりドキュメントをベクトル表 現する。

（2）ICA を適用し，基準語を取得する。

（3）基準語を元に $\chi^{2}$ 值にしたがって共起語を選別する。

（4）基準語と共起語を合わせたものを索引語とし，ド キュメントベクトルを作成する。

（5）関連フィードバックを用いてユーザープロファイ ルを作成する。

（6）ドキュメントの推薦を行い，11 点平均適合率を用 いて評価を行う。

また，提案手法の索引語選別による低次元化の有効性を 検討するために, 索引語選別を行わない場合 (ORIG) と, ドキュメントベクトルの低次元化で用いられる潜在的意味 解析 (LSA) を用いた場合の実験を行った。 
$\langle 4 \cdot 2\rangle$ 実験結果 まず，小規模なデータに対して行っ た実験結果を表 3 に示す。

つぎに，NTCIR2 を用いた実験の結果を示す。まず， $R_{b}$ を $10 \%$ に設定し，その基準語から索引語数を $R_{i}=10 \%$, $30 \% ， 50 \%$ として，選別したときの 11 点平均適合率を表 4 に示す。 $R_{b}$ が $30 \%$ のときの 11 点平均適合率を表 5 に 示す。すべての基準語を用いたときの 11 点平均適合率は表 6 である。最後に, 比較実験の結果として, 索引語選別を 行わなかった場合（ORIG）と，LSA による結果を表 7 に 示す。

\section{5. 検討と考察}

まず，表 3 に示されている，小規模なデータにおける実 験結果について検討する。独立成分によって得られる全基

表 3 小規模実験の結果

Table 3. 11-point average precisions of the small experiment.

\begin{tabular}{|c|l|l|l|}
\hline$R_{i} R_{b}$ & $10 \%$ & $30 \%$ & $A L L$ \\
\hline $10 \%$ & 0.23 & 0.45 & 0.63 \\
\hline $30 \%$ & 0.16 & 0.85 & 0.85 \\
\hline $50 \%$ & 0.14 & 0.67 & 0.85 \\
\hline ORIG & \multicolumn{3}{|c|}{0.63} \\
\hline
\end{tabular}

表 $4 R_{b}=10 \%$ の 11 点平均適合率

Table 4. 11-points average precision of $R_{b}=10 \%$.

\begin{tabular}{|l|l|l|l|l|l|l|l|l|l|}
\hline Task No. & 109 & 110 & 111 & 114 & 115 & 119 & 121 & 147 & 148 \\
\hline \hline $10 \%$ & 0.46 & 0.24 & 0.65 & 0.21 & 0.56 & 0.34 & 0.65 & 0.80 & 0.06 \\
\hline $30 \%$ & 0.55 & 0.25 & 0.71 & 0.36 & 0.59 & 0.47 & 0.69 & 0.81 & 0.05 \\
\hline $50 \%$ & 0.60 & 0.25 & 0.69 & 0.36 & 0.59 & 0.51 & 0.71 & 0.81 & 0.05 \\
\hline
\end{tabular}

表 $5 R_{b}=30 \%$ の 11 点平均適合率

Table 5. 11-points average precision of $R_{b}=30 \%$.

\begin{tabular}{|l|l|l|l|l|l|l|l|l|l|}
\hline Task No. & 109 & 110 & 111 & 114 & 115 & 119 & 121 & 147 & 148 \\
\hline \hline $10 \%$ & 0.34 & 0.24 & 0.47 & 0.27 & 0.46 & 0.46 & 0.61 & 0.77 & 0.12 \\
\hline $30 \%$ & 0.49 & 0.20 & 0.68 & 0.40 & 0.59 & 0.51 & 0.66 & 0.81 & 0.06 \\
\hline $50 \%$ & 0.61 & 0.22 & 0.71 & 0.41 & 0.60 & 0.56 & 0.70 & 0.82 & 0.06 \\
\hline
\end{tabular}

表 6 基準語をすべて用いた時の 11 点平均適合率 Table 6. 11-points average precision using the all basic words.

\begin{tabular}{|l|l|l|l|l|l|l|l|l|l|}
\hline Task No. & 109 & 110 & 111 & 114 & 115 & 119 & 121 & 147 & 148 \\
\hline \hline $10 \%$ & 0.38 & 0.23 & 0.47 & 0.20 & 0.47 & 0.40 & 0.61 & 0.68 & 0.13 \\
\hline $30 \%$ & 0.39 & 0.21 & 0.52 & 0.29 & 0.47 & 0.52 & 0.63 & 0.80 & 0.12 \\
\hline $50 \%$ & 0.52 & 0.17 & 0.69 & 0.37 & 0.59 & 0.55 & 0.69 & 0.81 & 0.05 \\
\hline
\end{tabular}

\section{表 7 比較実験の 11 点平均適合率}

Table 7. 11-points average precision of the Original and LSA.

\begin{tabular}{|l|l|l|l|l|l|l|l|l|l|}
\hline Task No. & 109 & 110 & 111 & 114 & 115 & 119 & 121 & 147 & 148 \\
\hline \hline ORIG & 0.60 & 0.25 & 0.72 & 0.38 & 0.61 & 0.63 & 0.72 & 0.82 & 0.05 \\
\hline LSA & 0.60 & 0.25 & 0.72 & 0.38 & 0.61 & 0.63 & 0.72 & 0.82 & 0.09 \\
\hline
\end{tabular}

準語を用いた場合に，索引語選別を行わないものに比べて 11 点平均適合率が改善していることがわかる。したがって, 本手法による索引語選別を行うことにより, 情報フィルタ リングの精度改善を見込めると考えられる。

さらに，一般的な見解を得るために，テストコレクショ ンを用いた実験の結果について検討を行う。表 7 と表 4 を 見比べると，多くのデー夕において， $R_{i}$ を $50 \%$ にすれば, ORIG や LSA と同程度の推薦精度を得ることができてい る。また， $R_{i}$ を $10 \%$ から $50 \%$ へ大きするにしたがって， 推薦精度が向上することも分かる。これは, 索引語の数が 増えることで, よりドキュメントの特徵付けが容易になった ためと考えられる。一方, No.110, No.147, No.148 といっ たデータにおいては, 索引語数を減らしても精度はあまり 変わっておらず, これらのデー夕に対しては, ドキュメント を表現するために必要な索引語を的確に選別できていると 考えられ, 本手法で索引語選別を行うことが有効であると 思われる。また，No.119 のデータに関しては， $R_{i}=50 \%$ としても, 従来手法と同程度の精度を得ることができなかっ た。No.119のデータの特徵を考えると, 全ドキュメント数 が 380 件と少ない割に, ORIG の全索引語数が 8,388 語と 他のデー夕に比べて多い。そのため，ひとつひとつの文書 を表現するために必要な索引語数が多く, 削減をすること でそれらの表現精度が低下したと考えられる。

つぎに，表 5 に着目する。 $R_{b}=30 \%$ の場合も，先ほどの $10 \%$ の場合の結果と同様の傾向が見られる。つまり, 索引 語数を増やしていくことで, 推薦精度は向上し， $R_{i}=50 \%$ とすると, 多くのデータにおいて従来手法と同程度の推薦 精度を得ることができる。また，No.119 のデータにおい ても表 4 の結果に比べると, 全体的に精度向上が見られる が従来手法よりは低い精度となっている。一方, No.114 と No.148のデータにおいては，精度改善が図れていることが 分かる。とくに, No.148の索引語数を $10 \%$ にした場合の 結果においては，ORIGに比べて改善が見られる。

表 6 について見てみると，この場合においても，No.148 において改善が見られる。一方, 基準語数を増やすことで, No.110のように, 索引語数を増やしても推薦精度が従来手 法に比べて低下しているものも見受けられる。これは, ICA によって得られる独立成分の表すトピックに含まれるノイ ズの影響を受けたと考えられる。

最後に, 表 4 表 6 を比較する。 $R_{b}=10 \%$ から $R_{b}=$ $30 \%$ にすると多くのデータで全体的に推薦精度があがって いる。しかし, 全基準語を使うようにすると, $R_{b}=30 \%$ に 比べて推薦精度は低下しているデータが多い。これは, 使 用する基準語数が少なすぎると特定のトピックに偏りすぎ てしまい, すべてのドキュメントを表現する上で必要な索 引語が得られない。一方, 使用する基準語数が多すぎると, トピックとして意味をなさない ICA の成分からも基準語を 取るため, 不必要な索引語が選ばれる可能性がある。した がって, 使用する基準語は多すぎても少なすぎても推薦精 度という意味では不適切であるといえる。 
さらに, 低次元化の一般的な手法である LSA に比べる と, 表 7 から本手法は同程度の推薦精度を得ることができ る。また，本手法は，潜在的意味空間上でドキュメントを 表現せずに，ドキュメントから直接得ることができる索引 語空間上で次元削減を行うことができるので，ドキュメン トの追加やクエリーによる検索などにおいて LSA より柔 軟に対応できると考えられる。

このように，本手法は同程度以上の推薦精度を維持しつ つ, ORIGに比べてメモリの効率化や処理時間の短縮を図 ることができる。また，従来の潜在的意味空間を用いる手 法とも同等の推薦精度を維持できることが分かった。一方, テストデータによって適切な基準語数, 索引語数が異なる ため, その決定方法については今後検討する必要がある。

\section{6. まとめ}

本論文では，ICA によって得られるトピックに基づいて， 索引語を選別し, それらの索引語からドキュメントベクト ルを作成し, 関連フィードバックによる推薦を行ってその 有効性を確認した。その結果, 索引語を削減しても, 推薦 精度はほぼ同程度ないし, 場合によっては改善が見込める ことが分かった。また，この手法で得られるドキュメント ベクトルは索引語によるので, 索引語拡張やクエリー検索 などの手法への応用も柔軟に対応できる。今後は基準語数 や索引語数決定のために, トピックの選別を行う必要があ ると考えられる。

(平成 18 年 8 月 28 日受付, 平成 19 年 3 月 14 日再受付)

\section{文献}

(1) M. Morita and H. Hayami: "Information Filtering System -Prescriptions for Information Flood-", Journal of Information Processing Society of Japan, Vol.37, No.8, pp.751-758 (1996) (in Japanese)

森田昌弘・速見治夫:「情報フィルタリングシステム—情報洪水への処 方箋一」, 情報処理学会学会誌, Vol.37, No.8, pp.751-758 (1996)

(2) G. Salton and M.J. McGill: "Introduction to Modern Information Retrieval", McGraw-Hill Book Company (1983)

(3) Y. Matsuo and M. Ishizuka: "Keywords Extraction from a Document using Word Co-occurrence Statistical Information", Transactions of the Japanese Society for Artificial Intelligence, Vol.17, No.3, pp.213-227 (2002) (in Japanese) 松尾 豊·石塚 満:「語の共起の統計情報に基づくドキュメントから のキーワード抽出アルゴリズム」, 人工知能学会誌, Vol.17, No.3, pp.213-227 (2002)

(4) Y. Ohsawa, N. Benson, and M. Yachida: "KeyGraph: Automatic Indexing by Segmenting and Unifing Co-occurrence Graphs", Transaction of the Institute of Electronics, Information and Communication Engineers, D, Vol.J82-D, No.2, pp.391-400 (1999) (in Japanese)

大澤幸生・ネルス E. ベンソン・谷内田正彦：「KeyGraph：語の共 起グラフの分割・統合によるキーワード抽出」, 信学論 D, J82-D, 2, pp.391-400 (1999)

(5) A. Hyvārinen and E. Oja: "Independent component analysis: A tutorial", Neural Network, Vol.13, pp.411-430 (2000)

(6) E. Bingham, A. Kaban, and M. Girolami: "Topic Identification in Dynamical Text by Complexity Pursuit", Neural Processing Letters, Vol.17, No.1, pp.69-83 (2003)

(7) T. Kolenda and L.K. Hansen: "Independent Components in Text", Advances in Independent Component Analysis, Springer-Verlag (2000)
(8) T. Yokoi, H. Yanagimoto, and S. Omatu: "Improvement of Information Filtering by Independent Component Analysis", Trans.IEE of Japan, Vol.126-C, No.4, pp.492-497 (2006-4) (in Japanese) 横井 健・柳本豪一・大松 繁：「独立成分の選択に上る情報推薦の 改良」, 電学論, 126-C, 4, pp.492-497 (2006-4)

(9) J. Rocchio: "Relevance feedback in information retrieval", The SMART Retrieval System Experiments in Automatic Document Processing, pp.313-323 (1971)

(10) S. Deerwester, T. Dumais, T. Landauer, W. Furnas, and A. Harshman: "Indexing by Latent Semantic Analysis", Journal of the Society for Information Science Vol.41, No.6, pp.391497

(11) A. Hyvārinen and E. Oja: "A fast fixed-point algorithm for independent Component Analysis", Neural Computation, Vol.9, No.7, pp.1483-1492 (1997)

(12) "NTCIR2", NII-NACSIS Test Collection for IR System, http://research.nii.ac.jp/ntcir/index-en.html

(13) Y. Matsumoto: "Japanese Morphological Analysis System: CHASEN", Information Science Technical Report NAIST-ISTR97007, Nara Institute of Science Technology (1997)

（14）長尾 真：「自然言語処理」, 11 章, 岩波書店 (1996)

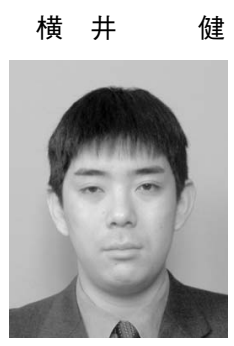

健 （正員） 1980 年生。 2007 年 3 月大阪府立大学大 学院工学研究科博士後期課程修了。 2007 年 4 月 より東京都立産業技術高等専門学校ものづくり工 学科電子情報工学コース助教となり現在に至る。 2005 年度電気学会電子・情報・システム部門大 会奨励賞，2006 年度電気関係学会関西支部連合 大会奨励賞受賞。主として情報検索に関する研究 に従事。IEEE 会員。博士 (工学)。

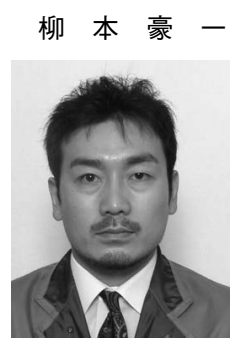

(正員) 1972 年生。1996 年大阪府立大学大学院 工学研究科博士前期課程修了。同年日本電気 (株) 入社。2000 年より大阪府立大学工学部助手とな り現在に至る。情報検索, 進化型計算手法に関す る研究に従事。博士 (工学)。情報処理学会, 計 測自動制御学会, システム制御情報学会会員。

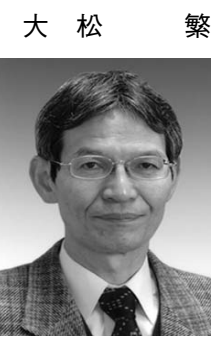

（正員） 1946 年生。1974 年大阪府立大学大学院博 士課程修了。同年徳島大学工学部情報工学科助手。 1988 年同知能情報工学科教授。1995 年大阪府立 大学工学部情報工学科教授となり, 現在に至る。 1991 年電気学会学術振興賞・論文賞, 1995 年計 測自動制御学会論文賞, 1996 年市村賞, 2005 年 電気学会業績賞受賞。ニューラルネットワークの 研究に従事。IEEE Trans. on Neural Network の Associate Editor (1992-2004)。システム制御学会, 計測自動制御 学会, IEEE 会員。工学博士。 